\title{
A Comparative Study of Soil Weed Seed Bank Determination in Pothwar Region by using Different Methodologies
}

\author{
Mubashir Hussain ${ }^{1}$, Safdar Ali ${ }^{1}$, Muhammad Naveed Tahir ${ }^{1}$, Ghulam Abbas Shah ${ }^{1}$, Ijaz Ahmad ${ }^{2 *}$, \\ Muhammad Aqeel Sarwar ${ }^{3}$ and Sohail Latif ${ }^{4}$
}

${ }^{1}$ Department of Agronomy, Pir Mehr Ali Shah, Arid Agriculture University, Rawalpindi, Pakistan; ${ }^{2}$ Ecotoxicology Research Institute, National Agricultural Research Centre Islamabad, Pakistan; ${ }^{3}$ Crop Sciences Institute, National Agricultural Research Centre, Islamabad, Pakistan; ${ }^{4}$ Research Farm Crops, Agriculture Department, AJ and K, Baldmas District Kotli, Pakistan.

Abstract | Soil weed seed bank is a natural source for weed infestation. Determination of soil weed seed bank has primary importance to get complete picture of weed seed reservoir in the soil profile. An experiment was conducted at University Research Farm, Chakwal Road, Rawalpindi to compare the techniques for determination of soil weed seed bank during winter 2012-2013 under rainfed conditions of Pothowar. Soil samples for the weed seed bank analysis were taken from the experimental field before wheat sowing from $0-10 \mathrm{~cm}, 11-20 \mathrm{~cm}$ and $21-30 \mathrm{~cm}$ soil depth. Two soil weed seed bank determination techniques were compared viz., sieving method and seedling emergence method. The data were collected on the seed density $\mathrm{m}^{-2}$, seed frequency, diversity of weed species and relative importance value. The input and output data was also collected to find out the socioeconomic feasibility of the techniques. The comparative analysis of seed bank extraction methods revealed higher weed seeds density, weed frequency with more diversity of weed species under sieving method in comparison to seedling emergence method. Therefore, sieving method was considered superior over seedling emergence method. The feasibility analysis of seed bank extraction methods indicated that sieving was cost-effective, less time consuming, more user friendly with higher accuracy over seedling emergence method.

Received | September 29, 2017; Accepted | October 27, 2017; Published | November 21, 2017

*Correspondence | Ijaz Ahmad,Ecotoxicology Research Institute, National Agricultural Research Centre Islamabad, Pakistan; Email: ijazswc@ gmail.com

Citation | Hussain, M., S. Ali, M.N. Tahir, G.A. Shah, I. Ahmad, M.A. Sarwar and S. Latif. 2017. A comparative study of soil weed seed bank determination in pothwar region by using different methodologies. Pakistan Journal of Agricultural Research, 30(4): 310-315.

DOI | http://dx.doi.org/10.17582/journal.pjar/2017/30.4.310.315

Keywords | Comparative study, Weed seed bank, Sieving method, Seedling emergence method

\section{Introduction}

Qoil acts as storage house for different macro and microorganisms including insects, micro-organism, fungi, algae, spores, nematodes and seeds of different weeds. Weed plants after maturation shed their seeds and these weed seeds ultimately accumulated in the soil profile which form weed seed bank in the soil. Soil weed seed bank comprises of all viable, dormant and non-dormant seeds present in the soil profile (Forcella et al., 2003). Knowledge of soil weed seed bank is important for population dynamics studied, establishment of appropriate weed management programs (Ambrosio et al., 2004) and forecasting of weed infestations (Ball and Miller, 1989; Creech et al., 2008). 
Weed seeds may enter in the seed bank through many sources from plant seed production, together with primary and secondary dispersal such as farm equipment, contaminated crop seeds, animals, wind and manure (Buhler et al., 1997). Among these sources, the largest source of weed seeds in the seed bank is plants producing seed within the field. Weed seeds also drive the spread of weed patches in fields, both for annual (Steinmann and Klingebiel, 2004) and perennial weed species (Blumenthal and Jordan, 2001), and are the only source of population increase for annual weed species. Decline in weed seed bank may occur by various factors such as germination, seed predation (Van Mourik et al., 2005), seed decay and death (Gallandt, 2006) and deep seed burial to layers from where emergence onto the soil surface is impossible (Honda, 2008). These seed banks range from near 0 to as much as 1 million seeds $\mathrm{m}^{-2}$ (Radosevich et al., 1997).

There are a number of methods that have been used to determine the density and composition of soil weed seed bank. These methods are categorized into two main techniques that are used to find out the number of seeds from the soil samples, i.e. (1) weed seed extraction method and (2) weed seedling emergence method. In direct seed extraction method, weed seeds are extracted by washing and floatation methods while in the second technique, weed seedling emergence, the soil sample is placed in the greenhouse or controlled environment, watered on regular basis in order to emerge the weed seedling and these emerged seedlings are then identified and counted (Luschei, 2003).

The objective of current study was the determination of soil weed seed bank of Pothowar region and to compare different methods to find out the most accurate, efficient, handy and economical technique for the determination of soil weed seed bank.

\section{Material and Methods}

A comparative study of soil weed seed bank determination methods was conducted during 2012-2013. Soil sampling was done from the different localities of the wheat field at University Research Farm, Chakwal Road Rawalpindi. Sampling of the soil was carried out before the sowing of wheat crop diagonally in four replications from three depths i.e. $0-10 \mathrm{~cm}$, $11-20 \mathrm{~cm}$ and $21-30 \mathrm{~cm}$. Soil samples were taken by using steel probe of $2.5 \mathrm{~cm}$ diameter for each method from each replication. The soil cores of same depth were bulked and mixed to make composite soil samples. These composite soil samples were divided into three working sub-samples having one hundred gram weight of each sample for soil weed seed bank analysis. The soil samples were then transported to laboratory and stored at room temperature until further processing. Two soil weed seed bank determination techniques i.e. seed extraction using sieving method and seedling emergence method were compared for extraction of weed seeds from soil. In sieving method, seeds were extracted from soil by sieving of soil sample through various sieves with different mesh sizes using method adopted by Konstantinović et al. (2011). Each 100 gram soil sample was initially poured on sieve of 80 mesh size and placed in the water for softening the soil clods. This sample was then immersed in the sodium hexa-metaphosphate solution $(40 \mathrm{~g} / \mathrm{L}$ of water) in order to disintegrate the soil particles. The soil samples were shifted to the bucket having tap water and shook well so that almost all clay and silt particles were filtered out and removed from sample. The remaining material on the sieves was air dried and transferred on the filter $\mathrm{pa}^{-}$ per so that samples become completely dried. These dried samples were then passed through a descending series of sieves i.e. mesh no. 10, 18, 30, 40, 50 and 80. Entire seeds remained on the sieves were collected for identification and further processing. Seeds of different weeds were collected from experimental area and its surrounding with objective of reference collection for the weed seeds identification. Seeds extracted from soil were compared with the collected seeds to identify seeds using high magnification lens $(10 \mathrm{X})$ and seeds of each species were counted. Viability of seeds was determined by using crushing method, i.e. gentle pressure was applied to the seeds with the help of forceps and seeds that resisted this pressure were considered as viable and counted. Seedling emergence trial was carried out in the growth chamber keeping the controlled environment for germination of different Rabi weed seeds. Soil core samples weighing 100 gram were spread onto petri dishes in separate sections according to their depth and replication. These petri dishes were placed in the germination chamber. The temperature in the germination chamber was maintained from $20^{\circ} \mathrm{C}$ during day time (12 hours) to $8{ }^{\circ} \mathrm{C}$ during night time (12 hours). Petri dishes were watered on daily basis avoiding samples to dry. Emergence of weed seedlings was observed on weekly basis. Emerged weed seedlings were identified 
Table 1: Detail of different weed species found in soil weed seed bank.

\begin{tabular}{|c|c|c|c|c|}
\hline \multicolumn{2}{|l|}{ Botanical name } & \multicolumn{2}{|c|}{ Common name } & Local name \\
\hline \multicolumn{2}{|l|}{ Anagallis arvensis } & \multicolumn{2}{|c|}{ Blue pimpernel } & Billibooti \\
\hline \multicolumn{2}{|c|}{ Asphodelus tenuifolius } & \multicolumn{2}{|l|}{ Jungle onion } & Piazi, Bhokat \\
\hline \multicolumn{2}{|c|}{ Avena fatua } & \multicolumn{2}{|l|}{ Wild Oat } & Jangli Jai \\
\hline \multicolumn{2}{|c|}{ Carthamus oxyacantha } & \multicolumn{2}{|l|}{ Wild safflower } & Pohli \\
\hline \multicolumn{2}{|c|}{ Chenopodium album } & \multicolumn{2}{|l|}{ Lambsquarter } & Bathu \\
\hline \multicolumn{2}{|c|}{ Convolvulus arvensis } & \multicolumn{2}{|l|}{ Field bindweed } & Lehli \\
\hline \multicolumn{2}{|c|}{ Euphorbia dracunculoides } & \multicolumn{2}{|l|}{ Dragon spurge } & Hermal \\
\hline \multicolumn{2}{|c|}{ Euphorbia helioscopia } & \multicolumn{2}{|l|}{ Sun spurge } & Chatridhodak \\
\hline \multicolumn{2}{|c|}{ Fumaria indica } & \multicolumn{2}{|l|}{ Fumitory } & Shahtra, Papra \\
\hline \multicolumn{2}{|l|}{ Melilotus indica } & \multicolumn{2}{|c|}{ Yellow sweet clover } & Senji \\
\hline \multicolumn{2}{|l|}{ Lathyrus aphaca } & \multicolumn{2}{|c|}{ Wild cow pea } & Janglimatar, $\mathrm{m}$ \\
\hline \multicolumn{2}{|l|}{ Vicia sativa } & \multicolumn{2}{|l|}{ Common vetch } & Revari \\
\hline \multicolumn{5}{|c|}{$\begin{array}{l}\text { Table 2: Total seed density } m^{-2} \text { and Shannon's diversity } \\
\text { index value under three soil depths determined through } \\
\text { two methodologies. }\end{array}$} \\
\hline & & \multicolumn{3}{|c|}{$\begin{array}{ll}\text { Seed densi- } & \text { Shannon's Index } \\
\text { ty } \mathrm{m}^{-2} & \text { of Diversity }\end{array}$} \\
\hline \multirow[t]{3}{*}{ Sieving Method } & $0-10 \mathrm{~cm}$ & \multicolumn{3}{|c|}{$28488 \quad 1.22$} \\
\hline & $11-20 \mathrm{~cm}$ & 18898 & \multicolumn{2}{|c|}{1.37} \\
\hline & $21-30 \mathrm{~cm}$ & n 13479 & \multicolumn{2}{|l|}{1.18} \\
\hline \multirow{3}{*}{$\begin{array}{l}\text { Seedling Emer- } \\
\text { gence Method }\end{array}$} & $0-10 \mathrm{~cm}$ & 11373 & \multicolumn{2}{|l|}{0.87} \\
\hline & $11-20 \mathrm{~cm}$ & 5285 & 0.84 & \\
\hline & $21-30 \mathrm{~cm}$ & n 3259 & 0.74 & \\
\hline
\end{tabular}

using a reference key of Hussain (2012), counted and removed at regular intervals. Unidentified seedlings were transferred to another pot and allowed to grow until seedling becomes identified. The trial ended when seedling emergence had stopped. Parameters like seed density $\mathrm{m}^{-2}$, species diversity index, relative importance value, and socioeconomic feasibility analysis were assessed to compare these soil weed bank determination methods. Seed density $\left(\mathrm{m}^{-2}\right)$ was determined by counting number of seeds in each sample of $100 \mathrm{~g}$ soil extracted through sieving method and seedling emergence method and then they were converted into number of seeds per $\mathrm{m}^{2}$ by multiplying the product with bulk density of that soil multiplied with 1000 (Kroschel, 2001; Elsafori et al., 2011). Weed species with a high RI value were considered to be the dominant species. The relative importance (RI) index was calculated by addition of relative density into relative frequency and the product was divided by 2 whereas, weed seed diversity was calculated by using Shannon and Weiner's diversity index (Magurran, 1988; Kobayashi et al., 2003).

\section{Seed/ Fruit description}

Capsule with dark brown angular seeds

Primulaceae

Liliaceae

Capsule with black trigonous seeds

Poaceae Caryopsis with straw colored hairy seed

Asteraceae Achene with shining grey color seeds

Chenopodiaceae Compound achene with black seeds

Convolvulaceae Capsule with brownish black seeds

Euphorbiaceae Ovoid seeds with grey or dark grey color

Euphorbiaceae Capsule (Cocci) with black seed

Fumariaceae Nut type seed

Fabaceae Single seeded pod with orange brown seeds

Legume with shining dark brown seeds

Fabaceae Legumes with greyish black seeds

$$
H^{`}=-\sum P \cdot \ln P
$$

\section{Where;}

P: n/N; n: No. of individuals of a species; N: No. of individuals of all species; Ln: Natural log.

\section{Results and Discussion}

\section{Seed bank composition}

From the soil samples taken from the wheat field, seeds of twelve Rabi weed species were identified and separated viz., Chenopodium album, Fumaria indica, Asphodelus tenuifolius, Euphorbia helioscopia, Euphorbia dracunculoide, Convolvulus arvensis, Vicia sativa, Carthamus oxyacantha, Anagallis arvensis, Avena fatua, Lathyrus aphaca and Melilotus indica (Table 1).

\section{Seed bank density $\mathrm{m}^{-2}$}

According to total seed density $\mathrm{m}^{-2}$ data (Table 2), more weed seeds were extracted using sieving method with the densities of 28488, 18898 and $13479 \mathrm{~m}^{-2}$ as compared to seedling emergence method having seed density of 11373,5285 and $3259 \mathrm{~m}^{-2}$ at upper $0-10 \mathrm{~cm}$, middle $11-20 \mathrm{~cm}$ and $21-30 \mathrm{~cm}$ soil depths respectively. Extraction of individual weed species seeds from soil samples through sieving method, were higher than seedling emergence method at all three soil depths. Only 11, 12 and 9 weed species were extracted from upper, middle and lower soil depths respectively in sieving method out of total twelve weed species seeds present in weed seed bank, whereas seeds of only 8, 7 and 6 weed species were emerged from the samples taken from $0-10 \mathrm{~cm}, 11-20 \mathrm{~cm}$ and $21-30 \mathrm{~cm}$ soil depths respectively through seedling emergence method (Table 3). 
Table 3: Seed bank density $m^{-2}$ under three soil depths determined through two methodologies.

\begin{tabular}{lllllll} 
& \multicolumn{5}{l}{ Sieving Method } & \multicolumn{3}{c}{ Seedling Emergence Method } \\
& $\mathbf{0 - 1 0} \mathbf{~ c m}$ & $\mathbf{1 1 - 2 0} \mathbf{~ c m}$ & $\mathbf{2 1 - 3 0} \mathbf{c m}$ & $\mathbf{0 - 1 0} \mathbf{~ c m}$ & $\mathbf{1 1 - 2 0} \mathbf{c m}$ & $\mathbf{2 1 - 3 0 ~} \mathbf{~ m}$ \\
Anagallis arvensis & 131.7 & 45.8 & 45 & 0 & 0 & 0 \\
Asphodelus tenuifolius & 2370.8 & 1956.1 & 1199.4 & 1198.6 & 811.2 & 811.2 \\
Avena fatua & 0 & 45.8 & 0 & 31.9 & 0 & 0 \\
Carthamus oxyacantha & 45.6 & 91.4 & 0 & 0 & 0 & 0 \\
Chenopodium album & 14658 & 8968.3 & 6689.7 & 5095 & 1962 & 1962 \\
Convolvulus arvensis & 953.1 & 763.1 & 765.3 & 692.1 & 683.2 & 683.2 \\
Euphorbia dracunculoides & 131.7 & 87.8 & 0 & 0 & 0 & 0 \\
Euphorbia helioscopia & 584.7 & 711.9 & 315.6 & 97.1 & 88.1 & 88.1 \\
Fumaria indica & 7630.3 & 4526.7 & 3118.1 & 3968.4 & 1519.7 & 1519.7 \\
Melilotus indica & 1057.8 & 891.7 & 853.3 & 225.4 & 159.8 & 159.8 \\
Lathyrus aphaca & 783.3 & 631.9 & 449.2 & 63.8 & 61.4 & 61.4 \\
Vicia sativa & 140.6 & 177.2 & 43.9 & 0 & 0 & 0
\end{tabular}

Table 4: Species relative importance value under three soil depths determined through two methodologies.

\begin{tabular}{lllllll} 
& \multicolumn{5}{l}{ Sieving Method } & \multicolumn{5}{l}{ Seedling Emergence Method } \\
& $\mathbf{0 - 1 0} \mathbf{~ c m}$ & $\mathbf{1 1 - 2 0} \mathbf{c m}$ & $\mathbf{2 1 - 3 0} \mathbf{c m}$ & $\mathbf{0 - 1 0} \mathbf{c m}$ & $\mathbf{1 1 - 2 0} \mathbf{c m}$ & $\mathbf{2 1 - 3 0 ~ c m ~}$ \\
Anagallis arvensis & 1.56 & 0.37 & 0.53 & 0 & 0 & 0 \\
Asphodelus tenuifolius & 12.8 & 12.13 & 11.31 & 16.4 & 14.96 & 17.207 \\
Avena fatua & 0 & 0.37 & 0 & 0.33 & 0 & 0 \\
Carthamus oxyacantha & 0.3 & 1 & 0 & 0 & 0 & 0 \\
Chenopodium album & 34.53 & 34.26 & 40.25 & 26.09 & 22.13 & 33 \\
Convolvulus arvensis & 7.98 & 7.33 & 8.09 & 12.51 & 25.41 & 15.1 \\
Euphorbia dracunculoides & 0.86 & 1.22 & 0 & 0 & 0 & 0 \\
Euphorbia helioscopia & 4.14 & 5.66 & 4.21 & 7.3 & 15.6 & 15.53 \\
Fumaria indica & 24.08 & 23 & 22.57 & 24.67 & 13.22 & 17.17 \\
Melilotus indica & 7.84 & 8.85 & 6.21 & 11.81 & 6.32 & 1.98 \\
Lathyrus aphaca & 4.95 & 4.94 & 5.93 & 0.84 & 2.35 & 0 \\
Vicia sativa & 0.96 & 0.88 & 0.91 & 0.05 & 0 & 0
\end{tabular}

\section{Diversity index of weeds species}

The Shannon index for diversity of the weed seed bank was ranged from 1.18 to 1.37 , depending on the soil sampling depths while using the sieving method (Table 2). In this method, Shannon's index of weed seeds diversity was high in middle depth having 1.37 value which indicates more number of species found at this depth and it was followed by upper depth having 1.22 index value whereas, minimum index value 1.18 was recorded at lower depth which indicates that under deeper layer of soil the seeds of different weed species may be decomposed with time who have lesser longevity of seeds. In case of seedling emergence method, the diversity index value ranged from 0.74 to 0.87 . It was minimum in the lowest depth (0.74), while it was higher 0.87 and 0.84 at upper and middle soil layers respectively which showed that the trend of data in both experimental methods was similar.

\section{Relative importance value of seed species}

Species seed bank relative importance was differed significantly by methods. The RI value data (Table 4) indicate that using sieving method, Chenopodium album, Fumaria indica and Asphodelus tenuifolius showed comparatively higher dominance/importance value in soil seed bank at all three upper, middle and lower soil depths. These weed species also showed dominance in case of seedling emergence method at the depth of 0-10 cm, whereas, Convolvulus arvensis, Euphorbia belioscopia and Asphodelus tenuifolius were found more dominant at middle $11-20 \mathrm{~cm}$ soil depth. Likewise, species like Chenopodium album, Asphodelus tenuifolius 
and Fumaria indica were dominated at $21-30 \mathrm{~cm}$ soil depth extracted by seedling emergence method.

\section{Economic analysis}

The data regarding economic analysis of both soil weed seed bank extraction techniques are presented in $(\mathrm{Ta}-$ ble 5). The total cost for each method was calculated including soil sampling cost, equipment cost for each method and labor cost. An amount of Rs. $(24,280)$ was spent in case of sieving method as compared to seedling emergence technique where Rs. $(29,480)$ were spent on germination and evaluation of weeds seeds. These results showed that sieving method is more cost effective than seedling emergence method.

Table 5: Cost Analysis of soil weed seed bank determination techniques.

$\begin{array}{lll}\text { Particulars } & \begin{array}{l}\text { Treatments } \\ \text { Sieving Method }\end{array} & \begin{array}{l}\text { Seedling Emer- } \\ \text { gence Method }\end{array} \\ \text { Cost of Sieves } & 4200 & 0 \\ \text { Labor charges for sieving } & 4800 & 0 \\ \text { Magnifying glass } & 200 & 0 \\ \text { Backlight board } & 2000 & 0 \\ \text { Petri dishes } & 0 & 10800 \\ \text { Water Bottles } & 0 & 200 \\ \text { Labor charges for water- } & 0 & 6000 \\ \text { ing purpose } & & 0 \\ \text { Sodium-hexa-meta-phos- } & 800 & \\ \text { phate } & 12480 & 12480 \\ \text { Soil sampling cost } & \text { Rs. } 24280 & \text { Rs. } 29480 \\ \text { Total Cost } & \end{array}$

This comparative study of sieving and seedling emergence methods has found contrasting results. Sieving method detected greater seed density $\mathrm{m}^{-2}$ and species diversity of soil seed bank compared with seedling emergence techniques. The seedling emergence method can considerably underestimate weed seed bank density $\mathrm{m}^{-2}$ due to errors associated with seed dormancy and specific environmental requirements for germination. The lower weed seed density $\left(\mathrm{m}^{-2}\right)$ noted in seedling emergence method may be attributed to dormant seeds present in the weed seed bank that probably did not germinate/ emerge, whereas both dormant and non-dormant weed seeds were extracted using sieving method and was not influenced by germination requirements which are necessary for seedling emergence method. These results are in line with the findings of Bernhardt et al. (2008), Wright and Clarke (2009), who reported more weed seeds using sieving method than seedling emergence method.
Bernhardt et al. (2008) found that about 90\% of all viable seeds found through the weed seed extraction method were not germinated using seedling emergence method.

The differences in species diversity of the soil seed bank between the two methods were in agreement to the results of Price et al. (2010), who found large differences in species composition of the soil seed bank between both sieving and seedling emergence methods at various soil depths. More species were extracted from sieving methods as compared to seedling emergence method. More frequently occurring weed species in the weed seed bank were Chenopodium album, Fumaria indica, Asphodellus tenuifolius, Convolvulus arvensis, Euphorbia helioscopia, Melilotus indica and Lathyrus aphaca and they were also found abundantly as above ground flora in studied area. Results of this study are in line with findings of Qureshi et al. (2011) who reported the higher abundance of these species in the study area (University Research Farm, Chakwal Road, Rawalpindi).

\section{Conclusion}

From the results, it can be concluded that both soil weed seed bank techniques were suitable for determination of seed bank but a physical separation of seed from the soil by sieving method proved effective for more weed seed counts either dormant or nondormant and better individual species detection as more weed species were detected in the seed bank using this method. Two techniques provided different estimates of the relative importance value of individual weed species in the seed bank. Sieving method is economically cost effective and less laborious. Final results for weed seeds counts can be obtained in less time using sieving method as compared to seedling emergence method which may take long time for weed seed germination.

\section{Author's Contribution}

Mubashir Hussain managed the experiment while Safdar Ali supervised the experiment. Muhammad Naveed Tahir, Ghulam Abbas Shah and Ijaz Ahmad provided technical input at every step. Muhammad Aqeel Sarwar and Sohail Latif wrote the article.

\section{References}

Ambrosio, L.A., L.Iglesias, C. Marin, and J.P.Monte. 2004. Evaluation of sampling methods and 
assessment of the sample size to estimate the weed seedbank in soil, taking into account spatial variability. Weed Res. 44: 224-236. https:// doi.org/10.1111/j.1365-3180.2004.00394.x

Ball, D.A. and S.D. Miller. 1989. A comparison of techniques for estimation of arable seed banks and their relationship to weed flora. Weed Res. 29: 365-373. https://doi. org/10.1111/j.1365-3180.1989.tb01307.x

Bernhardt, K.G., M. Koch, M. Kropf, E. Ulbel and J. Webhofer. 2007. Comparison of two methods characterising the seed bank of amphibious plants in submerged sediments. Aquat. Bot. 88: 171-177. https://doi.org/10.1016/j. aquabot.2007.10.004

Blumenthal, D. and N. Jordan. 2001. Weeds in field margins: a spatially explicit simulation analysis of Canada thistle population dynamics. Weed Sci. 49:509-519. https://doi.org/10.1614/0043 -1745(2001)049[0509:WIFMAS]2.0.CO;2

Buhler, D.D., R.G. Hartzler and F. Forcella. 1997. Implications of weed seedbank dynamics to weed management. Weed Sci. 45:329-336.

Creech, J.E., A. Westphal, V.R. Ferris, J. Faghihi, T.J. Vyn, J.B. Santini and W.G. Johnson. 2008. Influence of winter annual weed management and crop rotation on soybean cyst nematode (Heterodera glycines) and winter annual weeds. Weed Sci. 56:103-111. https://doi. org/10.1614/WS-07-084.1

Elsafori, A.K., A.N. Guma and M.A. E1 Nour. 2011. Soil seed banks of a rangeland area White Nile State, Sudan. J. Horticult. Forest. 3: 178-185.

Forcella, F., T. Webster and J. Cardina. 2003. Protocols for weed seed bank determination in agro-ecosystems. Weed Management for Developing Countries. Addendum 1.

Gallandt, E.R. 2006. How can we target the weed seedbank? Weed Sci. 54:588-596. https://doi. org/10.1614/WS-05-063R.1

Honda, Y. 2008. Ecological correlations between the persistence of the soil seed bank and several plant traits, including seed dormancy. Plant Ecol. 196:301-309. https://doi.org/10.1007/ s11258-007-9360-3

Hussain, A. 2012. Weed Identification Manual. Directorate of Agronomy, Ayub Agricultural Research Institute, Faisalabad.

Hussain, M. 2014. Comparative study of soil weed seed bank determination methods under different tillage system in rainfed wheat (Triticum aestivum L.). M. Sc. (Hons.) Thesis Dept. Agro., Pir Mehr Ali Shah Arid Agriculture University
Rawalpindi Pakistan.

Kobayashi, H., Y. Nakamura and Y. Watanabe. 2003. Analysis of weed vegetation of no-tillage upland fields based on the multiplied dominance ratio. Weed Biol. Manag. 3: 77-92.

Konstantinović, B., M. Meseldžija, M. Korać and B. Konstantinović. 2011. Study of weed seedbank in soybean crop. Afr. J. Agric. Res. 6(10): 23162320.

Kroschel, J. 2001. A Technical manual for parasitic weed res. and extension. Kluwer Academic Publishers, Dordrecht, The Netherlands. https://doi.org/10.1007/978-94-010-0005-5

Luschei, E.C. 2003. Comparison of the effectiveness of seedbank sampling to seedling counts in reducing the uncertainty in estimates of weed population size. Asp. Appl. Biol. 69:137-142.

Magurran, A.E. 1988. Ecological diversity and its measurement. Princeton University Press, Princeton.

Qureshi, R., G.R. Bhatti and G. Shabbir. 2011. Floristic inventory of Pir Mehr Ali Shah Arid Agriculture University Research Farm at Koont and its surrounding areas. Pak. J. Bot., 43(3): 1679-1684.

Radosevich, S., Holt, J., Ghersa, C. 1997. Implications for Management, second ed. John Wiley and Sons, NY, USA. Weed Ecol. 589.

Steinmann, H.H. and L. Klingebiel. 2004. Secondary dispersal, spatial dynamics and effects of herbicides on reproductive capacity of a recently introduced population of Bromus sterilis in an arable field. Weed Res. 44(5): 388-396. https:// doi.org/10.1111/j.1365-3180.2004.00413.x

Van Mourik, T.A., T.J. Stomph, and A.J. Murdoch. 2005. Why high seed densities within buried mesh bags may overestimate depletion rates of soil seed banks. J. Appl. Ecol. 42: 299-305. https://doi.org/10.1111/j.13652664.2005.01016.x

Price, J.N., B.R. Wright, C.L. Gross and W.R.D.B. Whalley. 2010. Comparison of seedling emergence and seed extraction techniques for estimating the composition of soil seed banks British Ecological Society. Methods Ecol. Evol. 1: 151-157. https://doi.org/10.1111/j.2041210X.2010.00011.x

Wright, B.R. and P.J. Clarke. 2009. Fire, aridity and seed banks. What does seed bank composition reveal about community processes in fire-prone desert? J. Veg. Sci. 20: 663-674. https://doi. org/10.1111/j.1654-1103.2009.01051.x 